\section{Page of Stone}

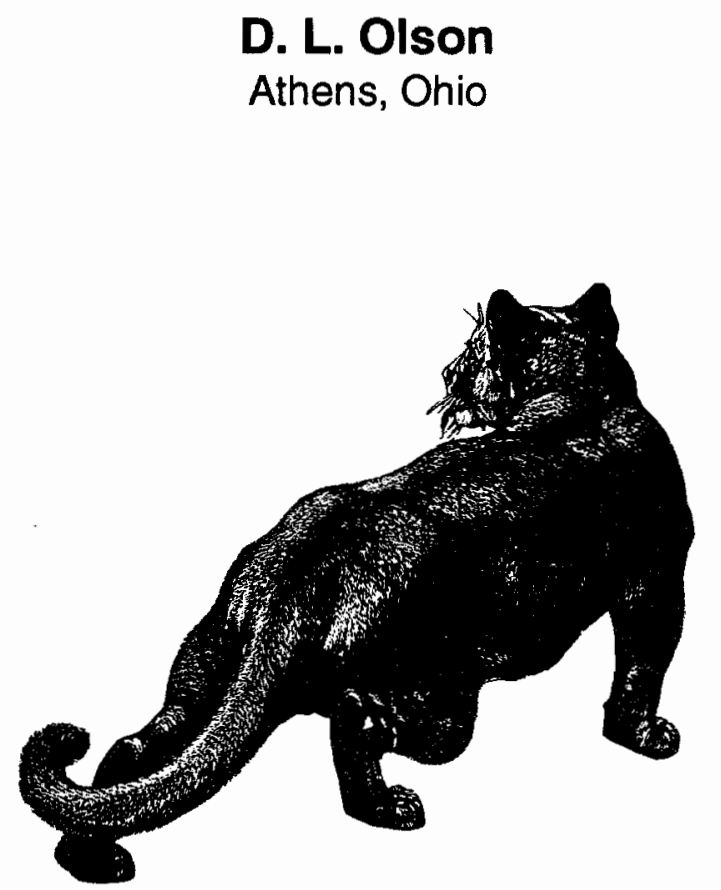

Dark Moon was gone, Low Cloud lamented. Gone forever. The Clan Wise Man had gone back to the place whence the Puma People, like all creatures treading upon the Great Mother's mesa or flying under the Great Father's sky, had come, and whither they would all return. And so never again would he see all the moons that had been and those to be and share this vision. Young Low Cloud had never known a time without Dark Moon's sage presence to reassure the Puma Clan of the Sky Father's constant blessings, even throughout this endless drought.

Not that Low Cloud allowed himself to be sad. That would be disrespectful. No, he was happy for Dark Moon like every other member of the Clan, none of whom thought the Earth Mother had called Her Wise Man back to Her womb too soon, because that would be blasphemy. Yet during the burial even the Sky Father Himself had shed misty tears, just enough to moisten His beloved Spouse's sandstone breast.

Dark Moon gone? It could not be. Yet it was. Because Low Cloud was not dreaming, but rather walking across the withering Sleeping Mesa's Sacred Long Arm toward a promised harvest awaiting him despite the many moons with almost no rain. Only three

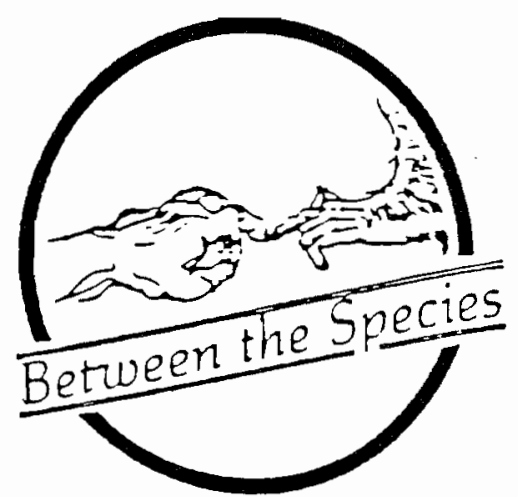

nights ago, Dark Moon had said in the Great Kiva, Low Cloud, Go out alone to the Long Arm's Fist and eat from the fruit that has ripened there and the Sky Father will bless you and the entire clan.

In the Great Kiva after the funeral the Elders had debated the wisdom of Low Cloud's solitary mission until the embers grew weary and fell asleep. And then Black Snake, the Clan's Eldest Elder, finally spoke. He said, During such a drought no pinyon forest on any mesa arm can offer up bounty, but if Dark Moon told Low Cloud to march out to the Fist and pick its fruit, then, Young Brother, you must go. The other Elders concurred in these wise words, and as one voice they asked the Sky Father to bless their Young Brother's undertaking beyond any hope or sense.

So now Low Cloud was treading among patches of withered corn in search of what could not be. And when he reached the mesa-top edge, he continued along the precipice. That the Puma Clan's Wise Man was gone forever kept striking him like a false omen, like a dream that was merely a dream and not a vision, but it was true. Worst of all, Dark Moon had left the Clan without naming a successor, a choice now up to the Sky Father alone. May it come soon, Low Cloud prayed. Not for his own sake, but for all his Puma Clan brothers and sisters and fathers and mothers.

A canyon wren's sharp trill brought him to an abrupt halt just as the brown sandstone beneath his feet

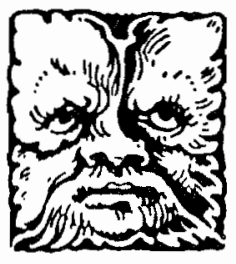


crumbled, and he threw himself away from the dropoff, thumping a leg hard into his Earth Mother's rocky breast. He quickly got up and dusted himself off and examined the fresh bruise and said, Thank you, Brother Wren. And thank you, Sky Father, for sending his feathered brother to warn me. Low Cloud bowed his head in shame for forgetting the Puma Clansman's first sacred duty in letting his thoughts flutter to and fro like a dead leaf eager to fall. He knew full well that every step of every act was to be done mindfully. Deliberately. Because each step was another word in a life-long prayer. Because to be alive was to pray. Because to breathe was to thank his Great Parents. Nothing else was the Puma Way.

Low Cloud carefully lowered himself off the mesa ledge and followed the path halfway down the side of the Long Arm. But if his dreaming with open eyes was wrong, he dared to ask himself, then why did the Sky Father allow it since Dark Moon had long since taught him to be mindful. It was almost as if the Sky Father were sending him, a mere young brave, a message. He longed for the departed Wise Man's understanding that could pierce the darkest of thoughts as a spear does the mule deer's tender flank, but, alas, that wisdom was gone.

Low Cloud ached for his spouse, White Deer. As the buck does the doe, pollen the pistil, flint fire, the wandering Sky Father the parched and patient Earth Mother, Low Cloud longed to bless his wife. And then again. And again. Until they were both so exhausted they would slip into sleep as blissfully black as the stars on a rainy night.

But again he was not being mindful, so he prayed aloud to force concentration. Low Cloud, the son of the Sky Father and of the Earth Mother, and of Thunder Cloud and Red Deer, and of the Sleeping Mesa, and of the Puma Clan. Low Cloud, who emerged from the Earth Mother's darkness to greet the Sky Father's brightness nineteen springs ago. Low Cloud, a fullgrown man for three summers now, his hair and eyes as black as his Great Father on a starless night, his skin as brown as his moist Great Mother two handspans deep where the blue corn seed is planted, his cheeks as high and strong as the Great Protector's jaws. Low Cloud, a man with a wife and daughter and son and his own room in the Puma Pueblo, built as solid by the whole Clan's hands as the sandstone shelf beneath their feet and the sheltering cliff hanging over their heads. And he thanked his Sacred Parents for the glorious gift of just being alive. Even in this drought the Sleeping Mesa was beautiful enough to bring tears to his eyes.

He stopped and scanned the cliff's edge above in hopes of a glimpse of the Great Protector, but Its fierce, unblinking eyes remained hidden. And then he asked the Sky Father to spill His bounty on the Earth Mother, to quench Her thirst and still Her hunger, so that all her withering children--from the corn and beans and squash and pinyon and juniper and flowers and lizards and birds and deer-might again flourish. And he asked the Great Father to bless his own widowed mother and her two surviving sisters and his dead aunt's husband as well as his own sister and her husband and their two boys. And he asked Him to bless White Deer and their children, that they might thrive and flourish. And he asked for a special blessing for Dark Moon who after his spouse found him as cold as morning ashes had been returned to his Earth Mother's womb.

Low Cloud kept praying until his shuddering back sensed the Protector's watchful snake eyes, his own thumping heart echoing Its muffled growl. And then he marched on toward the promised harvest at the end of the Mesa's Sacred Long Arm, with each step the atlatl bouncing against his hip and the spear shaft tapping his bare back and the water pouch slung over his shoulder sloshing. He was not carrying the weapon for selfdefense, but in the hope the Great Father might let his path cross a deer's. Though the ongoing drought had driven most of his forked-footed brothers closer to the sun, a migration some Elders were reading as a sign the Sky Father wanted the Puma Clan to follow. Dark Moon had never agreed.

On the Wise Man's last night in the Clan's Great Kiva, a brother from the distant Raven Clan had told of walking a week in vain search of firestone and of the Deer Clan's abandoning their sacred pueblo for the flatlands. Dark Moon had sat in silence a long time before he replied, How can any clan prosper by abandoning what their fathers' fathers had so carefully built unless the Sky Father commanded it Himself? As long as the Great Puma Protector, a son so cherished he carries His Earth Mother's own color, should remain on this mesa, the Puma Clan must stay as well.

Low Cloud himself wanted his people to remain on Sleeping Mesa until the Earth Mother opened into a bottomless canyon and swallowed the last of Her children. But it was not his role to speak, not before he himself became an Elder, which might come in five or six winters, the Great Protector willing, as it did 
for all the men of the Puma Clan. Except of course for those like Laughing Wind, a child for life no matter how many springs he might greet. But at only nineteen springs, Low Cloud still had to wait many, many moons. Even if already in ten or twelve winters, the Great Protector being patient, he would return to his Earth Mother's womb as Dark Moon just had. Which was good and as it should be. Because everything that happened was ultimately good, even the evil the Trickster enticed men into.

Without thinking, he grasped the water pouch slung over his left shoulder and then just as quickly let go. It was too long a journey yet to the promised pine nut harvest to drink so soon of the precious, clear milk oozing out ever more slowly from the crack in the Earth Mother's breast at the base of the Puma Pueblo.

All of a sudden Low Cloud shivered, but not from any cold. Though only in loin skins and yucca sandals, the Sky Father's direct brightness offered enough warmth, but Low Cloud sensed something ominous. And then the Great Protector, the Clan's Guardian Spirit, stepped before his very eyes, planting Its thick, strong paws upon a rock balancing over the trail. Low Cloud respectfully lowered his gaze, rejoicing that the Great Protector was overseeing his trek. He kept his gaze down until the Traveler's Guardian and the Great Spirit's Messenger and the Harvester of the Lame and the Sick silently withdrew. And then he thanked his Great Father and Mother for the honor just bestowed. Only twice before had he seen the Great Puma, and then only in the company of Dark Moon. So this was a powerful omen, but of what? He ached for Dark Moon's wisdom.

Low Cloud bent double and passed under the balancing rock, grains crumbling off the soft sandstone onto his back, to emerge on the other side, trembling with joy. And he walked on, now ignoring his thirst with ease. When a lizard leapt onto a flat stone in his path and pumped twice on its front legs, he instinctively reached for his spear. Was his little brother sending a warning? Or had something happened back at the Pueblo? He stared intently at his fellow creature, but it stood as still as a stone. Low Cloud hawked and grunted, begging it to say more, until it pumped twice again and jumped out of sight.

He stood a long time, pondering this new omen that Dark Moon would have instantly understood, until from high above the mesa top a vulture soared into view, and, by wriggling its two-tone wings, stopped on a column of air. Another sign. But of what? Low Cloud yearned for Dark Moon's sacred wisdom which could interpret fresh piles of fallen rocks, the calls of scrub jays, and the roll of thunder clouds. But all Low Cloud understood was that the Great Spirit was speaking. What He was saying he could not tell. To him it was like the garbled words of his father's brother whose right side the Protector had struck and left paralyzed three winters before the Great Mother took him back to her womb. Or like the gibberish of the Snow Clan scout who had visited the Puma Pueblo last summer. Though Dark Moon had understood that visitor too.

Dark Moon's gifts had been so many that they made Low Cloud feel clumsy like Laughing Wind, even though he had always readily learned everything the Elders knew to teach. How to hunt deer and gather pinyon nuts and juniper berries and prickly-pear fruit. How to build tiny, terraced plots to catch the scarce rain and how to plant the blue corn seeds and cull the weak seedlings so that the strong might thrive. And how to grind it into meal with a mano stone against a metate and then bake it with ashes to make the clan's sacred bread. And how to plant squash and beans and make them flourish as well. And he knew how to make soap from the broadleaf yucca's roots and rope, sandals, and baskets from its leaves. And he knew how to treat a runny nose and a sore throat with ephedra tea and stomach pains with juniper mistletoe. And he knew how to build roofs from the shaggy bark of the juniper, and stuff pillows and insulate sandals with it too. And he knew how to build a slow, clean pinyonwood fire that created little soot and left little ash. And he knew how to coax the fire from flint and make it leap into dry leaves. And he knew how to boil water behind the pueblo by heating round stones in the fire and picking them up with sticks and dropping them in the shallow pools. And he knew that the Mesa they lived and walked and slept on was as alive as the Puma People themselves and that the red sand was Her blood and the Mesa rock Her bones. And he knew that She had been alive long before they emerged from the Earth's belly and would be alive long after they had returned.

Like other Puma People, Low Cloud knew all these things, because the clan's survival depended on it. But without Dark Moon's blessed guidance he feared such knowledge would not be enough, so he prayed again for the Sky Father to choose a successor soon to the Puma Clan's Wise Man. But how would this man learn the sacred secrets without Dark Moon to teach him? 
Low Cloud came upon a scrub jay carcass swarming with tiny red ants and smiled at the Sky Father's gift so large it would take his little brothers days to carry the bounty home. They would feast their stomachs as round as the moon and enjoy the sleep of the blessed, as his own Clan had once done two generations ago when the Earth Mother kindly let it trap a whole herd of deer in a box canyon far to the north. In the Great Kiva the Puma Elders never tired of repeating accounts of this blessed hunting trip and of praying that someday, like their ancestors, they too might get a chance to sleep with bellies as full beside a deep, cold creek that never ran dry.

Low Cloud felt a strange urge to veer off the trail toward the red ants' home but instead marched on. And then up ahead of where his little brothers were streaming a dry twig broke. Quieter than a foraging ant, Low Cloud reached back and pulled his spear free and laid its blunt end against the atlatl, and, thanking the Sky Father for sending the gentle wind into his face, poised to throw. The heavy thump and scrape of a hoof on rock told him it was a deer. Low Cloud prayed that it be either a buck or a big doe and not a growing fawn. But he did not ask that he might kill it, because that was for the Great Father of all creatures alone to decide, and He needed no counseling. But if his spear was meant to fly, he prayed that his aim be true and the deer's suffering be brief. And in the knowledge that only life can feed life, he silently asked the unseen brother or sister for forgiveness.

Through a gap among dying juniper branches be made out long, erect ears and no horns. So it was a doe. The fellow creature fixed its big, black eyes on his face and lowered its head as if in acquiescence to Low Cloud's will. He could let his spear fly now and hope it missed the branches or he could wait and hope the deer moved into the clear.

Low Cloud quickly made his choice. But as he cocked a strong arm, a deep growl overhead startled the doe and it bounded out of sight. Low Cloud dropped his spear and stood up and faced the Great Protector, poised four man-lengths above, and bowed in respect, a chill quivering through his body. And he accepted the Great Father's wish that today was not for hunting.

And when he sensed the Sacred Mountain Lion had forgiven him, he offered a silent prayer of thanks and picked up his weapon and followed the column of ants wherever they might lead. And he smiled at the clouds piling up on the far horizon like white boiling-water stones. There was nothing he wanted more than for these Sky Brothers to keep growing and ripen, their Sky Father willing.

A rattle underfoot soon stopped Low Cloud midstep, and he carefully brought his foot back, nodding in respect at the Protector's legless brother. The snake slowly uncoiled and slithered into the shade of a withering yucca where it lifted its wedge-head and looked back.

Without hesitating, Low Cloud agreed to obey. And when it crawled on, he followed fearlessly until at the cliff's edge it slithered into a crack in the Earth Mother's breast and disappeared. There Low Cloud detected an aroma as rich and ripe as the Puma Protector's fresh droppings. And he closed his eyes and let his nose lead him along the precipice to an odorous patch of lowlying, dark green, tooth-leafed plants heavy with fruit. Instantly he recognized the thorny apples that Dark Moon had brought back from his lonely talks with the Sky Father to keep in his room.

When Low Cloud had once dared to ask him what they were, Dark Moon had said, It is the fruit of the Forbidden Plant, the Great Parents' sacred gift to Their chosen Wise Men. As the Puma People's Wise Man, he, Dark Moon, could use it without harm, but to anyone else it was pure poison-the roots, stalks, leaves, flowers, and above all the fruit.

Low Cloud bowed his head and inhaled the heady scent and thanked his Sacred Parents for the endlessness of Their bounty. And he prayed, Until the clouds walk over the horizon never to return and the Sky Father burns Himself up and the Earth Mother withers from grief, may the Puma People and all the other devoted children of the Sleeping Mesa flourish.

The sight of the Forbidden Fruit gently sleeping like the Mesa Mother herself made his heart thump with joy. But if it was pure poison, he wondered, then why had Dark Moon brought its white blossoms into the Great Kiva and laid them in the Sacred Center of Centers and Navel of Navels? And why had he harvested its fruit and kept it close by, since only the evil Snow People used poison, never the Puma Clan? Though the Sky Father's Legless Messenger and the Puma Protector's closest brother would strike out in self-defense with venomed teeth if any creature cornered him.

Low Cloud turned around to get back on the trail, but a dry rattle underfoot stopped him again. His legless brother once more lay coiled in the path, his mouth open to speak but making no sound. Low Cloud 
understood it anyway, and in obedience again faced the Forbidden Plant and glanced up at the watchful Great Protector perched atop a boulder. And he slowly reached for a toothed leaf, waiting for the Snake-Eyed Son of Heaven to growl or His Puma-eyed legless brother to rattle.

Neither made a sound. So Low Cloud twisted off a leaf and sniffed it, his nose curling up from the pungency. Could it be medicine? Because a plant smelled or tasted bad, did not mean it was not good. And if it was, then all the Puma men should know its secrets, as they did those of the juniper mistletoe and the ephedra bush. He crushed the large, dark-green leaf and rubbed its blood on a calloused palm. It left no stain. When he brought his moist hand to his nose, it smelled like White Deer nestling close at night.

He picked another leaf and crunched it gently between his teeth, grimacing at the plant's bitter blood, thinner than his own and saltless. He kept chewing until his mouth filled with saliva, which he half-swallowed before spitting the rest out.

No stinging, no itching, nothing bad. Was this really the Forbidden Plant? But the thorny apples that Dark Moon had brought home from his lonely talks with the Sky Father were unmistakable, what the big whitetubed flowers that Dark Moon placed inside the Sacred Great Kiva's Center of Centers and Navel of Navels eventually became.

So how could it be poison? Low Cloud's gaze met the four brotherly eyes still watching and approving. And so he plucked an apple and, ignoring the painful thorns, twisted it until flat, dark seeds spilled into his hand. He grabbed one and bit it in two.

Again no discomfort. The plant's blood tasted good like the Great Mother's most precious gift, the clear milk that seeps its way from deep within Her belly to emerge from a life-giving nipple. Bitter, but nonetheless good. And still no burning, no itching, no pain. So why had Dark Moon called it poison?

Low Cloud stepped over his little brother warming himself against their Earth Mother and resumed his journey. But he did not get far before his tongue and palate became so dry they stuck together and he felt a powerful thirst. Quickly he asked the Sky Father to bless the Earth and all His other loved ones as he himself would bless White Deer that night and then gulped two huge mouthfuls of the scarce Puma Pueblo spring water and only with great effort did not drink more. When he swung its pouch back over his shoulder, he lost his balance with a giggle and plopped down onto a flat rock and laughed until his belly hurt.

Had White Deer mischievously poured fermented corn juice into his water pouch? He sniffed it, but it smelled as pure as his newborn daughter's breath. What else could it be? He looked up at the heavens and thunderheads came rolling over the horizon, rumbling with good news. Yes! The Great Drought was about to end! The parched and patient Earth Mother was soon to be blessed! Yes! Oh, yes!

Lowering clouds kept crawling closer like Sky Snakes that winked and smiled. And the Sky Father roared like a pride of Great Protectors beyond counting and Low Cloud understood! Yes, I know! he bellowed, the Sleeping Mesa echoing his gales of laughter. Father! Mother! he shouted. Brothers! Sisters! One and All, my Great Sacred Family, all born of the Center of Centers and Navel of Navels, One with Us as We Are All One with You, hear my prayer! He is coming! Tears of joy ran down Low Cloud's cheeks.

A lizard leapt onto a stone at his feet and a scrub jay landed on a branch beside his head. Yes, Low Cloud shouted, the Sky Father and all His blessings are coming! And the three fellow creatures' joy brimmed and flowed and together they offered up their thanks. And Low Cloud told his little brothers of having come looking for a bounty of pinyon nuts, and the three shook with mirth over the mistake.

And the Great Sky Snakes rolled and churned in writhing coils and turned green and yellow and red and stretched out to every corner of the sky and the Great Father's thundering voice again spoke. Yes, Low Cloud answered humbly. Yes, he would pick up Dark Moon's burden. Yes, he would carry it till the Earth Mother took him back to Her womb, if that was His Great Father's will. And, yes, from that moment on, he would be known as Running Snake, just as Green Stone had once become Dark Moon. Yes! Oh, yes! And the Puma Clan's new Wise Man, Running Snake, staggered to his feet and leaned against his Great Mother for support, as he had once done as a tiny child. And then he let go and stood as tall as ripe corn ready for harvest.

And beneath his soles, Running Snake felt the Sleeping Mesa awakening, the many-armed stone mother that had always fed and clothed and warmed the Puma Clan with never a murmur of complaint. And before his eyes She bared her Sacred Center of Centers and Navel of Navels, and Running Snake peered down 
into it and beheld his fathers' fathers beyond counting emerge from Her belly and step up into the bright gaze of their loving Great Father. And he looked up at a Sky Snake billowing like a mushroom, and his own throbbing head buzzed with the screams and cries of sandy-skinned, hooded-eyed brethren pictured in the cloud burning alive from the touch of a giant sparkling bird's droppings. And he saw this clan, far, far greater in number than the Puma Clan, recover from this wound and prosper for moons beyond counting. And there was nothing that had been or would be that Running Snake could not see with open eyes.

He saw his son and daughter bent over from their burdens trekking toward the flatlands where the rivers never ran dry, where they and their children's children would prosper as long as they remembered their debt to their Sacred Parents and their kinship with all that was alive. And Running Snake wept with the fullness of the Sky Father's blessings, with His having chosen him, a man of only nineteen springs, as Dark Moon's successor and the Puma Clan's new Wise Man.

An eagle swept into view with a shrill whistle and perched on an unseen column, its rocking wings speaking to Running Snake who understood. And he raised his arms and blessed the Awakening Mesa on behalf of his Great Father and asked Her to prepare for the embrace of Her beloved spouse. And with deliberate steps Running Snake turned his back on the canyon and followed the hovering eagle to the great rock wearing the sacred blackness that the Sky Father's downpours over the generations had painted there. And he took the Sacred Mano waiting in his Earth Mother's sandy hand and quickly scraped the paint away to let the figures he saw beneath the dark mask shine through. And thus he traced the Puma People's history-from their emergence in their Sacred Mother's belly, through their journey to the Sleeping Mesa and their future trek to the flatlands toward the sun. And thus he recorded the dependence of the Puma Clan, like that of everything that had ever existed or would exist, on their Great Parents whose blessings knew no end.

And when Running Snake had finished and laid down the Mano, the Sacred Father flashed across the Sky and roared. And He let loose His blessings that poured down and drenched His beloved Spouse and all the grateful children to which They had given birth. And Running Snake stretchel his arms out like his eagle brother and threw back his head and opened his parched mouth and drank of the Great Spirit's abundance. Overhead on the mesa top, droplets joined into drops that became trickles that became rivulets that became streams that became a raging torrent rushing off the cliff to smash against Running Snake's prayer, the Sky Father's blessed caress neither smudging nor blurring a single line in the page of stone.

\section{Fireflies}

Not yet beautiful,

They rise like seeds at your feet

Where the first dark of the evening

Lies down in the damp grass.

Their wings beat beneath tiny shells

The color of earth.
Now it is night and they fly

into the darkness, wholly beautiful.

They flash and they float.

They are the stars of the earth

And you hold them in your hands

Beneath a sky of stars.

Kathryn Winograd 